\title{
HERBS USED AS ANALGESIC BY DAYAK TRIBE IN NORTH KALIMANTAN INDONESIA
}

\author{
Irma Novrianti ${ }^{1,2 *}$, Faizal Mustamin², Suharjono ${ }^{3}$ \\ 1,3 Department of Clinical Pharmacy, Airlangga University, Surabaya, \\ ${ }^{2}$ Academy of Pharmacy Kaltara Tarakan, Kalimantan Utara
}

Received August 28, 2019; Accepted February 04, 2020

\begin{abstract}
Traditional medicines produced from medicinal plants have played an important role in disease treatment in Dayak Tribe, North Kalimantan. Northern Kalimantan belongs to a remote area where health facilities like healthcare center (puskesmas - pusat kesehatan masyarakat) and hospital are not easily accessible. This research aims to investigate herbs used by Dayak tribe in North Kalimantan for treating pain. It is a descriptive research applying two research methods i.e. observation and interview. We directly observed the research object and proposed questions to respondents that were traditional healers from each village. The research was conducted in nine villages within three regencies in North Kalimantan. Meanwhile, 38 herbs collected in this research were from 26 families and 34 species. Four species were still locally named. The highest proportion of the herb family used was Asteraceae. The most frequently used part of the herb for medicine was the leaf $(60.53 \%)$. The main serving methods were by boiling the herb and drinking it $(63.15 \%)$. Bone pain and stomachache were two main illnesses mostly treated by local herb therapy involving 11 herbs. In conclusion, Dayak tribe in North Kalimantan still used herbs to treat their pain.
\end{abstract}

Keywords: analgesic; Dayak tribe; herb.

\section{INTRODUCTION}

Herbs have been processed into traditional medicine since thousands of years ago. The medicine was in the form of raw medicine such as tincture, tea, poultice, powder, and other herbal formulations (Archana et al., 2011). Indonesia is known as a country with its high diversity of plants. There is $10 \%$ of global flowering plant species existing in Indonesia. It is due to natural condition in Indonesia that is different in each island even in each region (Indrawan, 2007). Herbs are plants mainly used for traditional medicine. The use of herb is one of social habits since medicine made from herbs is more natural than modern medicine (Makalalag et al., 2014).

Pain is a body defense mechanism form when the body is having unpleasant emotion and sensor experiences related to potential or real tissue damage. Mediators such as interleukin-1, and TNF- $\alpha$ spread the synthesis, release, and acts of prostaglandin E1 (PGE2) and F2 $\alpha$ by endothelium and brain capillary pericytes that stimulate the nerves and may cause pain. Increasing prostaglandin content in peritoneum cavity increases the capillary permeability and causes pain (Nasrin et al., 2015). Conventional therapy used to treat pain such as analgesic, non-steroid antiinflammatory drugs (NSAID), and corticosteroid have been proven to succeed (Sreekeesoon \& Mahomoodally, 2014). The pain may vary from mild to severe. Some therapies such as opioid are alternated for more severe pain (Reid et al., 2015). Aloe vera (L) Burn is used as analgesic in Mauritus to treat leg pain and body pain (Sreekeesoon \& Mahomoodally, 2014). 
Most residents of Dayak tribe in North Kalimantan live in an area where they cannot easily access health facilities such as hospital and community health center due to the long distance. Living in an area next to the forest, they prefer to use herbs as medicine because of their affordability and accessibility (Yitno, 1991). This research aims to investigate herbs for pain management used by Dayak tribe in North Kalimantan.

\section{METHODS}

This research is descriptive in which the data were collected through observation and interview methods. Observation as a data collection technique was completed by the researcher by performing a direct observation towards the research object, while during interview, researchers proposed questions to respondents to investigate herbs used for pain management by Dayak tribe in North Kalimantan. The study was conducted for 3 months from March 2017 to June 2017 with permits directly addressed to customary leaders in their respective regions.

North Kalimantan is geographically located between $114^{\circ} 35^{\prime} 22^{\prime \prime}-118^{\circ} 03^{\prime} 00^{\prime \prime}$ east latitude and $4^{\circ} 24^{\prime} 55^{\prime \prime}-1^{\circ} 21^{\prime} 36^{\prime \prime}$ north latitude. North Kalimantan has a tropical climate and two seasons i.e. dry season and rainy season, which is similar to any other areas in Indonesia.

Interviews were performed to nine respondents who were traditional healers from several villages i.e. Lembudud, Long Kiwang, and Wayangung in Nunukan; Sekatak, Long Sam, and Pejalin in Bulungan; and Kaliamok, Sembuak Warod, and Tanjung Nanga in Malinau. We identified the respondents based on information given by local people. Data on characteristics of respondents and information related to the use of herbs were recorded. All interviews were conducted in the local language that was Dayak language. Meanwhile, research assistant acted as a translator of Dayak language into Indonesian.

The results of data collection including data on herb type, sample use, and the procedure of use obtained from interviews were further investigated through thorough observation.

Determination of respondents using snowball sampling method started with the Head of Customary Affairs. Afterwards, he gave recommendations and led the researcher to other respondents. Each respondent would be given information about medicinal plants.

Inventory of medicinal plants in the field was carried out by field survey method based on respondent information. Every plant obtained was taken their pictures; and their regional names as well as morphological characters were recoded. Identification process of medicinal herbs was performed by referring to several books entitled Buku Flora (Steenis et al., 2005), Kitab Tanaman Obat Nusantara (Widyaningrum, 2011) and Atlas Tumbuhan Obat Indonesia Jilid 4 (Dalimartha, 2006).

\section{RESULTS AND DISCUSSION}

The findings were discussed in three subparts i.e. traditional healer, ethnobotanical flora, and type of pain.

\section{Traditional Healer}

In this research, researcher collected information about herbs used to treat pain by communicating and interviewing one or two traditional healers of each village. The age range of those traditional healers was 40 up to 70 years old. Our respondents, the traditional healers, obtained their knowledge on herbs from their ancestors. Research on herbal medicine for diabetes conducted in Northeast Iran revealed that $87 \%$ of traditional healers learned herbs from their parents or other relatives (Tag et al., 2012). In another study, traditional healers acquired their medicinal plant knowledge by inheriting from their elder lineage (father or grandfather), whereas the rest received his medicinal plant knowledge from dreams (Nasution, Aththorick and Rahayu, 2018). In this research, traditional healers admitted that they received 50-100 patients in one month. Our field observation and interview with traditional healers during survey clarified that patients preferred traditional medicine to 
modern drugs due to its effectiveness, affordability, and accessibility.

\section{Patterns of Herbs Used among Dayak Tribe}

Information on herbs' scientific name, origin, family, and serving method is fully presented in Table 1.38 herbs gathered in this research were categorized into 26 families and 34 species. Four herbs were still locally named since they could not be identified by local botanical experts. The highest proportion of the herbs was Asteraceae (five species) followed by Euphorbiaceae, Fabaceae, Lamiaceae, and Malvaceae- each with two species and other families with one species for each. Asteraceae was the largest family of herb used to reduce pain in North Kalimantan. Based on research on herbs used to reduce pain in Mauritus (2014), it was confirmed that out of 79 herbs found, there were six species from Lamiaceae family, followed by Apiaceae, Asteraceae,
Euphorbiaceae, and Poaceae with five species each (Sreekeesoon \& Mahomoodally, 2014). Asteraceae was the largest family dominating plant vegetation on earth with the number of members of 24,000-30,000 species and 1,6001,700 genera globally spread in almost all types of environment (Bisht and Purohit, 2014). Besides, herbs commonly used by eastern people in Amazon came from Asteraceae, Lamiaceae, Euphorbiaceae, Piperaceae, and Verbenaceae families (Hariyadi, 2011). Asteraceae family could be used as traditional medicine since they contained bioactive compound components such as sesquiterpene, lactone, pentacyclic triterpene, alcohol, tannin, polyphenol, saponins, and sterol that could be used as medical ingredients. Due to its bioactive property, Astereaceae family was usually used as insecticide, anthelminthic, antimalarial, antiseptic, anti-inflammation, and antioxidant (Wegeira et al., 2012).

Table 1. Types of Herbs and Serving Methods Applied by Dayak Tribe in North Kalimantan

\begin{tabular}{|c|c|c|c|c|c|c|c|}
\hline No. & Family & Type & $\begin{array}{l}\text { Local } \\
\text { Name }\end{array}$ & $\begin{array}{l}\text { National } \\
\text { Name }\end{array}$ & $\begin{array}{l}\text { Used } \\
\text { Part }\end{array}$ & Treated Illness & Serving Method \\
\hline \multirow[t]{3}{*}{1.} & Acanthace & & & & & & \\
\hline & & \multirow{2}{*}{$\begin{array}{l}\text { Justicia gendarussa } \\
\text { burm }\end{array}$} & \multirow{2}{*}{$\begin{array}{l}\text { War } \\
\text { tonep }\end{array}$} & \multirow{2}{*}{ Ganda rusa } & \multirow{2}{*}{ Leaf } & Rheumatic & $\begin{array}{l}\text { Boil ten leaves. Drink } \\
\text { it thrice a day. }\end{array}$ \\
\hline & & & & & & $\begin{array}{l}\text { Bruise and } \\
\text { sprain }\end{array}$ & \\
\hline \multicolumn{8}{|c|}{ 2. Asteraceae } \\
\hline a. & & $\begin{array}{l}\text { Blumea } \\
\text { BalsamiFera }\end{array}$ & Ipung & Sembung & Leaf & $\begin{array}{l}\text { Stomachache, } \\
\text { menstrual pain }\end{array}$ & $\begin{array}{l}\text { Boil five up to seven } \\
\text { leaves. Drink it thrice a } \\
\text { day. }\end{array}$ \\
\hline b. & & Pluchea indica & Beluntas & Beluntas & Leaf & Stiffness & $\begin{array}{l}\text { Boil a handful of leaves } \\
\text { until the water } \\
\text { decreases. Drink it } \\
\text { thrice a day. }\end{array}$ \\
\hline c. & & Heliothous anuus L & $\begin{array}{l}\text { Bonga } \\
\text { mata } \\
\text { so’o }\end{array}$ & $\begin{array}{l}\text { Bunga } \\
\text { matahari }\end{array}$ & All parts & $\begin{array}{l}\text { Headache, } \\
\text { fuzziness, } \\
\text { toothache, } \\
\text { menstrual pain, } \\
\text { stomachache }\end{array}$ & $\begin{array}{l}\text { Take three handfuls of } \\
\text { flowers, add one } \\
\text { chicken egg (do not } \\
\text { break the egg) and } \\
\text { three glasses of water. } \\
\text { Boil them until the } \\
\text { water decreases. Drink } \\
\text { it twice a day after } \\
\text { meal. }\end{array}$ \\
\hline
\end{tabular}




\begin{tabular}{|c|c|c|c|c|c|c|c|}
\hline No. & Family & Type & $\begin{array}{l}\text { Local } \\
\text { Name }\end{array}$ & $\begin{array}{l}\text { National } \\
\text { Name }\end{array}$ & $\begin{array}{l}\text { Used } \\
\text { Part }\end{array}$ & Treated Illness & Serving Method \\
\hline d. & & Strobilanthescrispus & $\begin{array}{l}\text { Peca } \\
\text { beling }\end{array}$ & Peca beling & Leaf & Stomachache & $\begin{array}{l}\text { Boil ten leaves in three } \\
\text { glasses of water until } \\
\text { the water decreases. } \\
\text { Drink it thrice a day. }\end{array}$ \\
\hline \multirow[t]{2}{*}{3.} & Arecace & & & & & & \\
\hline & & Daemonorops & $\begin{array}{l}\text { Rotan } \\
\text { sembulik }\end{array}$ & $\begin{array}{l}\text { Rotan } \\
\text { jernang }\end{array}$ & Stem & Stomachace & $\begin{array}{l}\text { Boil and drink the } \\
\text { water thrice a day. }\end{array}$ \\
\hline \multirow[t]{2}{*}{4.} & Amaryll & aceae & & & & & \\
\hline & & $\begin{array}{l}\text { Crynum asiaticum } \\
L\end{array}$ & $\begin{array}{l}\text { Kaber } \\
l a b\end{array}$ & $\begin{array}{l}\text { Daun } \\
\text { bakung }\end{array}$ & Leaf & Sprain & $\begin{array}{l}\text { Grill the leaf and put it } \\
\text { on the painful area } \\
\text { once a day at night. }\end{array}$ \\
\hline \multirow[t]{2}{*}{5.} & Amaran & i aceae & & & & & \\
\hline & & $\begin{array}{l}\text { Gopheruna } \\
\text { globasa } L\end{array}$ & $\begin{array}{l}\text { Bonga } \\
\text { derem }\end{array}$ & Kenop & All parts & Headache & $\begin{array}{l}\text { Grind and put it on the } \\
\text { painful area. }\end{array}$ \\
\hline \multirow[t]{2}{*}{6.} & Apocyna & eae & & & & & \\
\hline & & $\begin{array}{l}\text { Plumeria } \\
\text { acuminate Ait }\end{array}$ & $\begin{array}{l}\text { Kamboj } \\
a\end{array}$ & Kamboja & $\begin{array}{l}\text { Leaf, } \\
\text { stem, } \\
\text { root }\end{array}$ & Toothache & $\begin{array}{l}\text { Pick the sap/leaf, } \\
\text { grind it and put it on } \\
\text { the painful area. }\end{array}$ \\
\hline \multirow[t]{2}{*}{7.} & Balsami & aceae & & & & & \\
\hline & & $\begin{array}{l}\text { Impatsens } \\
\text { Balsamia }\end{array}$ & $\begin{array}{l}\text { Kemban } \\
\text { g pacar }\end{array}$ & Pacar air & Leaf & $\begin{array}{l}\text { Menstrual } \\
\text { pain }\end{array}$ & $\begin{array}{l}\text { Grind the leaf and put } \\
\text { on the lower abdomen. }\end{array}$ \\
\hline
\end{tabular}

8. Crassulaceae

\begin{tabular}{|c|c|c|c|c|c|}
\hline & & & & Rheumatic & $\begin{array}{l}\text { Boil seven leaves and } \\
\text { drink the water twice a } \\
\text { day. }\end{array}$ \\
\hline Kalanchoe pinnata & $\begin{array}{l}\text { Sosor } \\
\text { bebek }\end{array}$ & $\begin{array}{l}\text { cocor } \\
\text { bebek }\end{array}$ & Leaf & Sprain & $\begin{array}{l}\text { Pick several leaves } \\
\text { and smear them with } \\
\text { oil. Grill then put it on } \\
\text { the painful area. }\end{array}$ \\
\hline
\end{tabular}

\section{Cycadaceae}

\begin{tabular}{|c|c|c|c|}
\hline $\begin{array}{l}\text { Cycas revolute } \\
\text { thumb }\end{array}$ & $\begin{array}{l}\text { Aka } \\
\text { kabuk }\end{array}$ & $\begin{array}{l}\text { Akar } \\
\text { penawar }\end{array}$ & Stem \\
\hline
\end{tabular}

Cut one $\mathrm{cm}$ of the stem, divide it into two, grind it, and soak it into water. Drink the water.

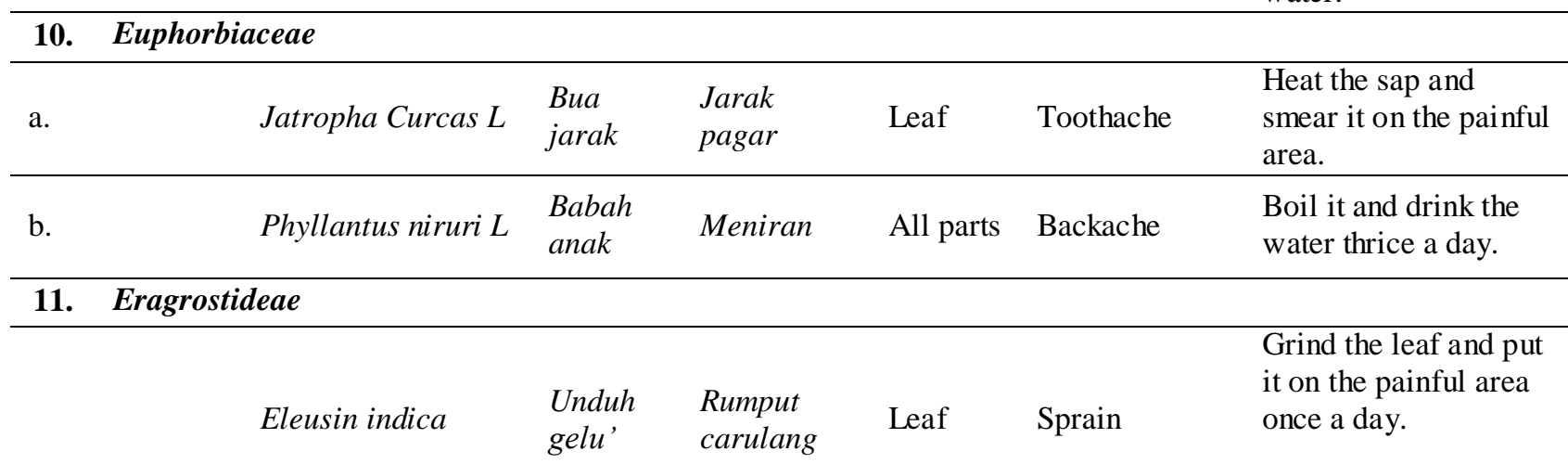


Jurnal Farmasi Sains dan Komunitas, 2020, 17(1), 30-40

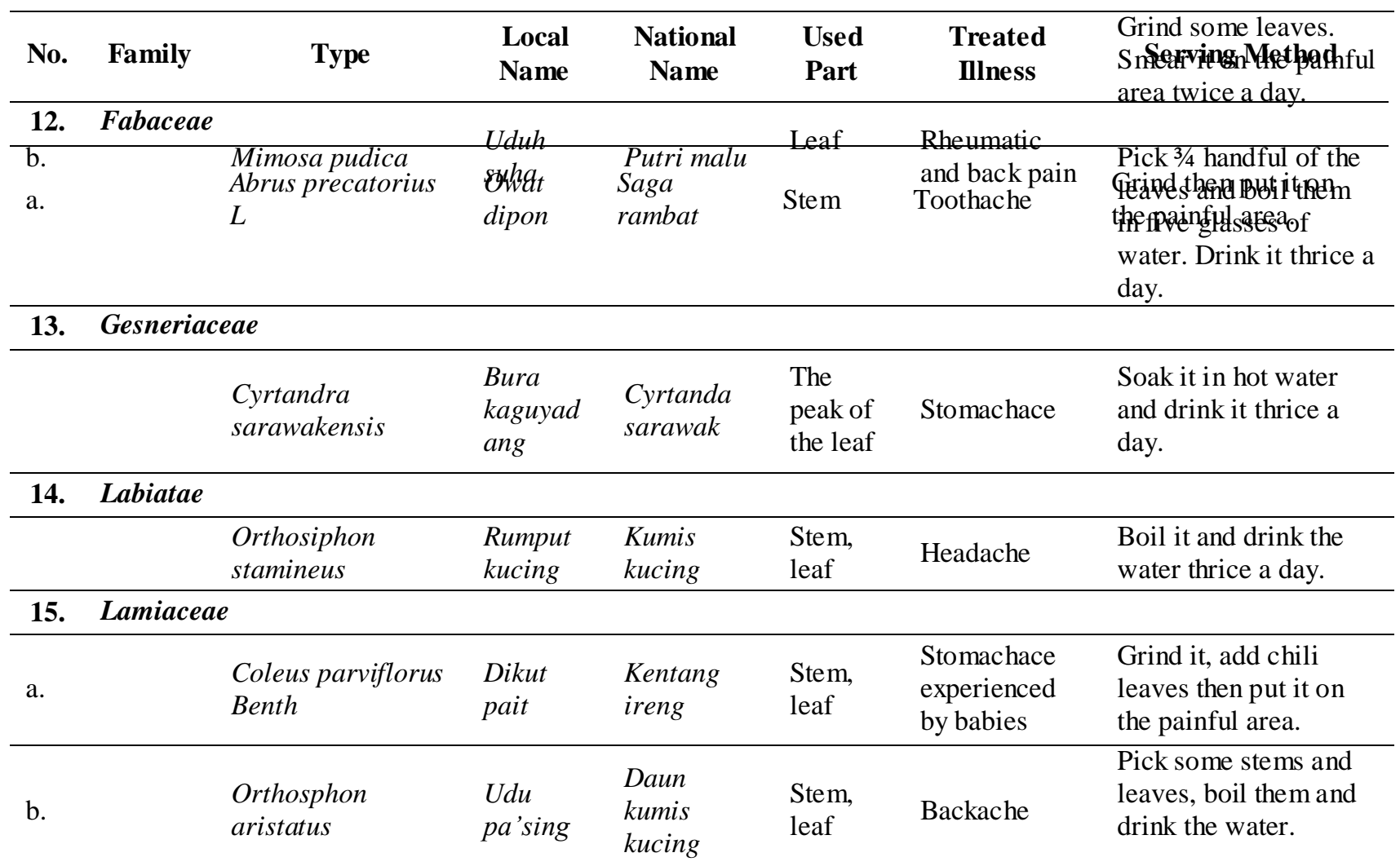

16. Loranthaceae

$\begin{array}{lll}\text { Loranthus Ancam Benalu All parts Toothache } & \begin{array}{l}\text { Burn it and mix } \\ \text { oil. Put it on the } \\ \text { painful area. }\end{array}\end{array}$

17. Malvaceae

$\begin{array}{lllll}\begin{array}{l}\text { Grewia acuminate } \\ \text { Juss. }\end{array} & \begin{array}{l}\text { Bura } \\ \text { krotok }\end{array} & \begin{array}{l}\text { Akar } \\ \text { sekapu }\end{array}\end{array} \quad \begin{aligned} & \text { Stem } \\ & \text { Stomachace }\end{aligned} \quad \begin{aligned} & \text { Burn it and drink the } \\ & \text { essence twice a day. }\end{aligned}$

Chop the leaf and

$\begin{array}{lllll}\text { Hibiscus rosa } & \text { Bunga } & \text { Kembang } & \text { Leaf, } & \text { Headache } \\ \text { sinensis L } & \text { sepatu } & \text { sepatu } & \text { flower } & \end{array}$

flower, and boil them in three glasses of water. Drink the water thrice a day.

18. Malastomataceae

\begin{tabular}{|c|c|c|c|c|c|}
\hline & & & Leaf & Stomachache & $\begin{array}{l}\text { Boil the leaf. Drink it } \\
\text { while still warm. }\end{array}$ \\
\hline $\begin{array}{l}\text { Melastonia } \\
\text { sepfemnerviu }\end{array}$ & $\begin{array}{l}\text { Jelemuti } \\
n\end{array}$ & Senggani & Stem & Toothache & $\begin{array}{l}\text { Peel and grind the } \\
\text { stem. Use it as your } \\
\text { mouthwash thrice a } \\
\text { day. }\end{array}$ \\
\hline
\end{tabular}

\begin{tabular}{|c|c|c|c|c|c|c|c|}
\hline No. & Family & Type & $\begin{array}{l}\text { Local } \\
\text { Name }\end{array}$ & $\begin{array}{c}\text { National } \\
\text { Name }\end{array}$ & $\begin{array}{l}\text { Used } \\
\text { Part }\end{array}$ & $\begin{array}{l}\text { Treated } \\
\text { Illness }\end{array}$ & Serving Method \\
\hline 19. & Menispe & naceae & & & & & \\
\hline & & \multirow[t]{2}{*}{ Tinospora crispa } & \multirow{2}{*}{$\begin{array}{l}\text { Bundung } \\
\text { kemamba } \\
\text { ng }\end{array}$} & \multirow[t]{2}{*}{ Brotowali } & Leaf & Stomachache & \multirow{2}{*}{$\begin{array}{l}\text { Pick the stem and cut } \\
\text { it. Boil it in three } \\
\text { glasses of water then } \\
\text { drink it thrice a day. }\end{array}$} \\
\hline & & & & & Stem & Rheumatic & \\
\hline
\end{tabular}

20. Musaceae 
Jurnal Farmasi Sains dan Komunitas, 2020, 17(1), 30-40

\begin{tabular}{|c|c|c|c|c|c|c|}
\hline & Musa & Peti & Pisang & Stem & $\begin{array}{l}\text { Joint pain and } \\
\text { bone pain }\end{array}$ & $\begin{array}{l}\text { Pick a stem and divide } \\
\text { it into two. Pick the } \\
\text { umbut and eat it. }\end{array}$ \\
\hline \multicolumn{7}{|c|}{ 21. Myrtaceae } \\
\hline & Psiatum guajava $L$ & Libum & Jambu biji & Leaf & Stomachache & $\begin{array}{l}\text { Pick and grind six } \\
\text { leaves. Pour some } \\
\text { water and squeeze the } \\
\text { leaves. Drink the } \\
\text { water. }\end{array}$ \\
\hline \multicolumn{7}{|c|}{ 22. Pandanaceae } \\
\hline & $\begin{array}{l}\text { Pandanus } \\
\text { amaryllifaius roxb }\end{array}$ & $\begin{array}{l}\text { Kaber } \\
\text { nanung }\end{array}$ & $\begin{array}{l}\text { Pandan } \\
\text { wangi }\end{array}$ & Leaf & $\begin{array}{l}\text { Rheumatic } \\
\text { and stiffness }\end{array}$ & $\begin{array}{l}\text { Pick and wash three } \\
\text { leaves. Cut them into } \\
\text { small size and brew } \\
\text { them with a half cup } \\
\text { of oil. Stir it. Let it } \\
\text { cold and smear it on } \\
\text { the painful area. }\end{array}$ \\
\hline \multicolumn{7}{|c|}{ 23. Poaceae } \\
\hline & $\begin{array}{l}\text { Cymbopogon } \\
\text { nardus } L\end{array}$ & Gisumau & Sere wangi & $\begin{array}{l}\text { Root, } \\
\text { young } \\
\text { leaf }\end{array}$ & Rheumatic & $\begin{array}{l}\text { Pick and boil some } \\
\text { roots and young leaves } \\
\text { in six glasses of water. } \\
\text { Boil until the water } \\
\text { decreases and drink it } \\
\text { thrice a day. }\end{array}$ \\
\hline
\end{tabular}

24. Rubiaceae

$\begin{array}{lll}\text { Concang } & \text { Abang } \\ \text { abstria sp. } & \text { All parts Pain killer } & \begin{array}{l}\text { Boil and drink it thrice } \\ \text { a day. }\end{array}\end{array}$

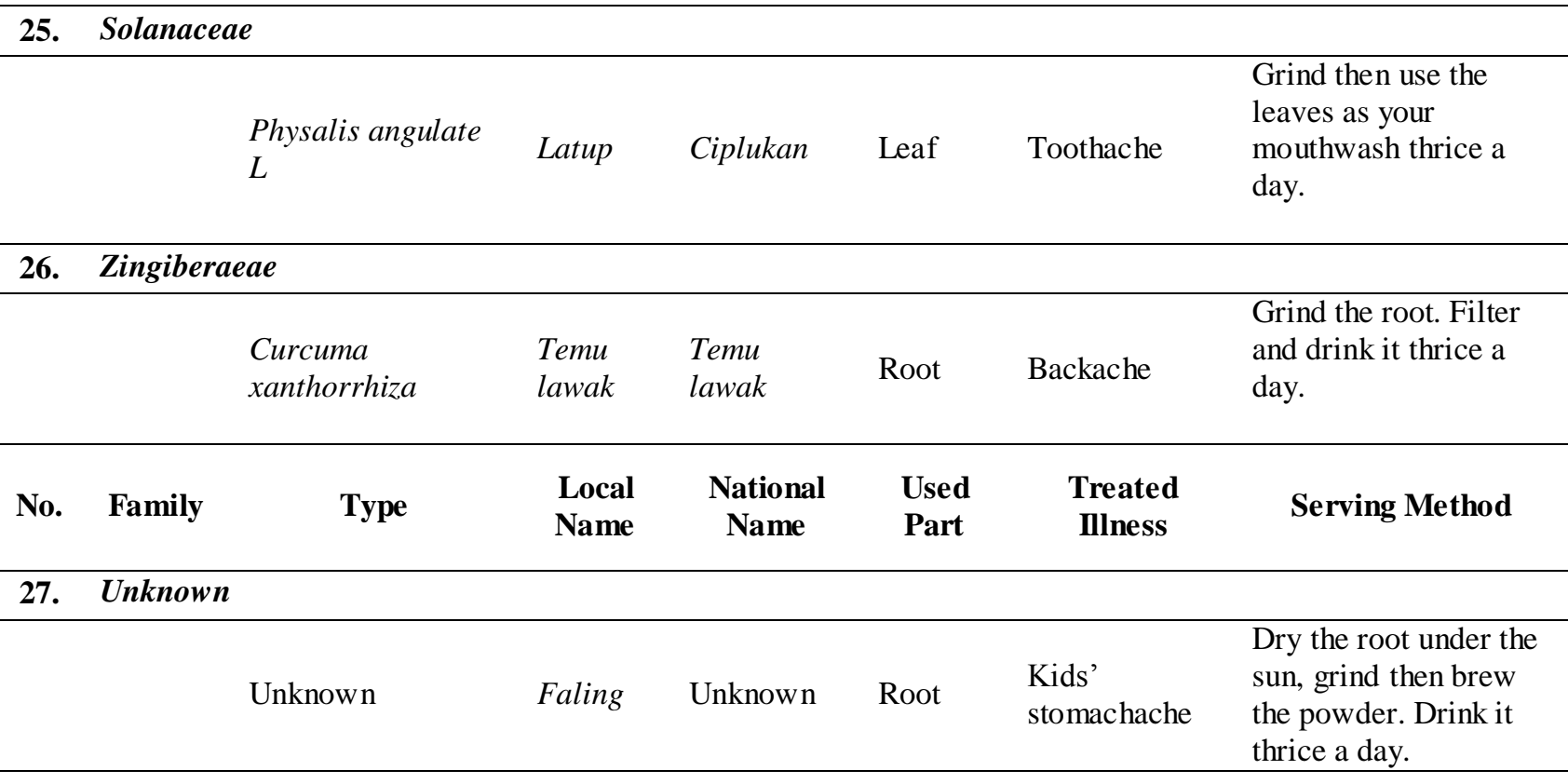




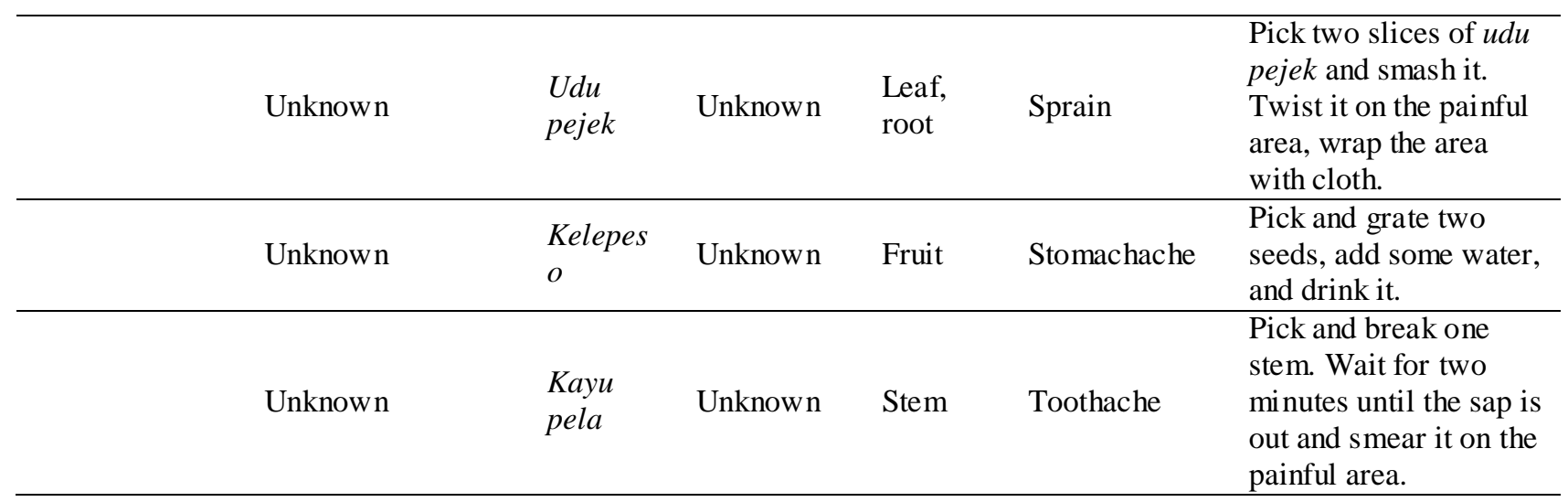

The most frequently used parts of the herbs for medicine were the leaf $(60.5 \%)$ and the stem $(26.3 \%)$. Meanwhile, the distribution of the herbs' parts used to treat pain is presented in Table 2. To manage pain, Dayak tribe in North Kalimantan preferred to use leaves of the selected herbs. The selection is important because the right part of herbs contains secondary metabolite that helps patients to obtain the desired therapeutic effect. In addition, leaf contains many active phytochemical pharmacologies responsible for curative effects (Sreekeesoon \& Mahomoodally, 2014). Ethnobotanical research in Dayak Tribe Seberuang in Ensabang Village conveyed that leaf was mostly used because people found it easier to collect leaves than to collect other parts of herbs that existed underground. Additionally, when they dug the ground, they might destruct the herb root, thus, harmed the herb (Damianus et al., 2013). Another research declared that most traditional healers used leaf to substitute part of herb that grew underground to preserve the herb (Traore et al., 2013). Besides, leaf is the most accessible part of herb. In addition, leaf could be more easily processed and gave more benefits (Takoy, Linda \& Lovadi, 2013). Herbal therapy containing many complex compounds was regarded to provide more action targets to human body (Raja Nasution, Aththorick and Rahayu, 2018).

Herbs could be used as medical treatment through several techniques like by drinking the herbs (63.2\%), putting the herbs on the painful area $(36.8 \%)$, and using the herbs as mouthwash (5.26) for toothache. The fact is shown in Table 3.

Serving methods can be completed by boiling and drinking them, or by rubbing them on the painful area. Boiling was the most common and efficient method (Sreekeesoon \& Mahomoodally, 2014). Methods applied to prepare the herbs were boiling $(42.1 \%)$ and grinding then smearing on the painful area $(36.8 \%)$, as presented in Table 4.

\section{Types of Pain}

Distribution of types of pain and number of herbs for pain management is shown in Table 5. Types of pain experienced were bone pain (rheumatic, sprain, backbone pain, and stiffness), stomachache, toothache, headache, backache, and menstrual pain. Out of those, bone pain and stomachache were two types of pain that were most frequently treated using herbs consisting of 11 herbs for each illness. Especially for headache, it could be cured with a certain therapy using nine types of herb.

One of herbs used to reduce bone pain was gandarusa. Justicia gendarussa Burm F. (Family: Acanthaceae) is widely used in Indian and Chinese traditional medicines and the leaf of the plant is recommended to treat pain such as arthritis, headache, earache, and muscle pain (Jaijesh et al., 2009). The herb could be found or cultivated in Indonesia, India, China, Malaysia, Sri Lanka, Philippine, and Bangladesh. The leaf of the herb was reportedly anti-angiogenic, antioxidant, anti-bactericidal, antifungal, anti-arthritis, anti-inflammatory, anti-nociceptive, and anti-sickling, and it 
showed anthelmintic, cytotoxicity, larvicidal, and adulticidal activity (Ningsih et al., 2015). Additionally, gandarusa contained flavonoid compound (Gustina, 2017) known to cure inflammatory disorders (Wegeira et al., 2012). Hence impeding Cox-2 formation and preventing prostaglandin formation.

Another herb used as a therapy for stomachache and menstrual pain was sambong (Blumea BalsamiFera). Blumea balsamifera (L.) DC. (Asteraceae), or sambong has been widely used in many countries such as Chinese, Malaysia, Thailand, Vietnam, and Philippine for years. The herb is widely used in Indonesian traditional medicines; the leaf of the plant is recommended to treat pain such as arthritis, headache, earache, and muscle pain (Rahardjo, 2016). It is the most important member in Blumea genus and the origin herb of tropical and subtropical Asia, particularly China. It grows in the edge of the forest, underneath the forest, river bed, valley, and meadow. All parts of the herb, including the leaves, were used as a traditional therapy to cure eczema, dermatitis, beriberi, backache, menorrhagia, rheumatic, and damaged skin, and as an insecticide. The main active compound contained in Sembong (Blumea BalsamiFera) is L-borneol characterized by high volatility. Besides, Sembong contained essential oil, flavonoid, and terpenoid with some different biological activities (Pang et al., 2014). It has many flavonoid compounds. There were 27 of 29 flavonoid compounds identified in Sembong (Blumea balsamifera (L.) DC) including 21 analog flavonoids, five derivative CQAs, and one coumarin (Pang et al., 2014). Antiinflammatory activity mechanism of flavonoid is restricting eicosanoid to produce some enzymes such as phospholipase A2, cyclooxygenases, and lipoxygenase, hence, reducing both leukotriene and prostanoid concentrations. Other mechanisms are histamine and phosphodiesterase restriction, protein kinase releases, and transcriptase activation. Restricted eicosanoid enzyme would restrict phospholipase A2 enzyme formation so that cyclooxygenase and lipoxygenase would be unable to be formed which cancelled the production of prostaglandin compound (Rathee et al., 2009).

Table 2. Distribution of the Used Parts of the Herbs

\begin{tabular}{cccc}
\hline No. & $\begin{array}{c}\text { Part of the } \\
\text { Herbs Used }\end{array}$ & Number & $\begin{array}{c}\text { Percentage } \\
(\boldsymbol{\%})\end{array}$ \\
\hline 1 & Leaf & 23 & 60.5 \\
2 & Stem & 10 & 26.3 \\
3 & Flower & 1 & 2.6 \\
4 & Fruit & 1 & 2.6 \\
5 & Root & 2 & 5.3 \\
6 & Flower & 1 & 2.6 \\
7 & All parts & 2 & 5.3 \\
8 & Herb & 1 & 2.6 \\
\hline
\end{tabular}

Table 3. Distribution of the Technique in Herbs Use

\begin{tabular}{cccc}
\hline No. & $\begin{array}{c}\text { Technique to } \\
\text { Use }\end{array}$ & Number & $\begin{array}{c}\text { Percentage } \\
(\boldsymbol{\%})\end{array}$ \\
\hline 1 & Oral & 24 & 63.2 \\
2 & Topical & 14 & 36.8 \\
3 & Mouthwash & 2 & 5.3 \\
\hline
\end{tabular}

Table 4. Distribution of Herbs Serving Methods

\begin{tabular}{clcc}
\hline No. & \multicolumn{1}{c}{ Serving Method } & Number & Percentage (\%) \\
\hline 1 & Boiling & 16 & 42.1 \\
2 & Grinding and smearing on the painful area & 14 & 36.8 \\
3 & Soaking into water & 3 & 7.9 \\
4 & Burning & 1 & 2.6 \\
\hline
\end{tabular}




\begin{tabular}{llll}
\hline 5 & Grinding and using the herb as mouthwash & 2 & 5.3 \\
6 & Mashing up by using a blending machine & 1 & 2.6 \\
7 & Shredding and adding water & 1 & 2.6 \\
8 & Brewing & 1 & 2.6 \\
9 & Eating & 1 & 2.6 \\
\hline
\end{tabular}

Table 5. Types of Pain and Herbs

\begin{tabular}{|c|c|c|c|}
\hline No. & Name of Illness & $\begin{array}{l}\text { Number of } \\
\text { Herbs }\end{array}$ & Herbs (Local Name) \\
\hline 1. & $\begin{array}{l}\text { Bone pain (rheumatic, sprain, } \\
\text { stiffness, backbone pain) }\end{array}$ & 11 & $\begin{array}{l}\text { Ganda Rusa, Sere Wangi, Cocor Bebek, } \\
\text { Putri Malu, Beluntas, leaf of Bakung, } \\
\text { Pandan Wangi, Pisang, Brotowali, Rumput } \\
\text { Carulan, Udu Pejek }\end{array}$ \\
\hline 2 & Stomachache & 11 & $\begin{array}{l}\text { Sambong, Rotan Jernang, Kentang Ireng, } \\
\text { root of Sekapu, Cyrtanda Sarawak, } \\
\text { Senggani, Jambu Biji, Peca Beling, } \\
\text { Brotowali, Faling, kelepeso. }\end{array}$ \\
\hline 3 & Toothache & 9 & $\begin{array}{l}\text { Kamboja, Ciplukan, Senggani, Jarak } \\
\text { Pagar, Bunga Matahari, Tahi kotok, Saga, } \\
\text { Benalu, Kayu Pela }\end{array}$ \\
\hline 4 & Headache & 4 & $\begin{array}{l}\text { Kumis Kucing, Kenop, Bunga Matahari, } \\
\text { Kembang Sepatu }\end{array}$ \\
\hline 5 & Backache & 3 & $\begin{array}{l}\text { Temu Lawak, Leaf of Kumis Kucing, } \\
\text { Meniran }\end{array}$ \\
\hline 6 & Menstrual pain & 2 & Pacar Air, Sembung \\
\hline 7 & Pain killer & 2 & Root of Penawar, Concanga-bang \\
\hline
\end{tabular}

One of the herbs used by Dayak people in North Kalimantan to cure toothache was benalu (Loranthus europaeus, family: Loranthaceae). World Health Organization (WHO) estimates that more than $80 \%$ of world population relies on traditional medicines and the market is rapidly growing. Lots of medicinal plants like Loranthus europaeus are recommended to treat pain (Nasrin et al., 2015). The herb is rich of flavonoid, alkaloid, terpenoid, and polysaccharide, and shows expressed gen toxicity, cytotoxic and antioxidant properties. Flavonoid is known for its ability to impede prostaglandin synthesis involved in the final phase of acute inflammation and pain perception. It can also increase the number of endogen serotonin or interact with 5-HT2A and 5-HT3 receptors involved in central analgesic activity mechanism. Terpenoid is also reported to show a significant analgesic activity whereas alkaloid can also prevent inflammation by blocking the metabolic path of arakidonat acid.
Loranthus europaeus contains flavonoid, alkaloid, terpenoid, polysaccharide, and other phytochemicals that cause analgesic activities. All parts of herbs can be used as medicine. However, in all of our experiments, extract of the leaves gave better effect than the stems which might be due to its higher phytochemical content (Nasrin et al., 2015).

\section{CONCLUSION}

This research figured out that Dayak people in North Kalimantan still used traditional medicine to cure pain and other illnesses. Traditional healers collected herbs in the forest and processed them into medicine and gave it to their patients. The most frequently used herb by Dayak tribe in North Kalimantan was from Asteraceae family while the most frequently used part was leaf. Furthermore, types of pain experienced by Dayak tribe in North Kalimantan were bone pain, stomachache, toothache, headache, 
backache, and menstrual pain. Effectiveness and safety of herbs reported to be potentially analgesic shall be evaluated within phytochemical and pharmacological studies to determine the dosage, minimum restriction concentration, bioactive compound, and toxicity.

\section{ACKNOWLEDGEMENT}

High appreciation and gratitude are specifically expressed to educational and social foundation of Kaltara, pharmacy academy of Kaltara, Kornalius, and Bungan as translator.

\section{REFERENCES}

Aleebrahim-Dehkordy, E., Mohammad, R.T., Nasri, H., Azar, B., Parto, N., Sara, B., 2017. Review of Possible Mechanisms of Analgesic Effect of Herbs and Herbal Active Ingredient. J Young Pharm, 9(3), pp.303-06.

Archana, Jatav, S., Paul, R., Tiwari, A., 2011. Indian Medicinal Plants: A rich source of natural immune-modulator. Int $J$ Pharmacol 7(2), pp.198-205.

Gustina, A.Y., 2017. Analisis Kandungan Flavonoid pada Berbagai Usia Panen Gandarusa (Justicia gandarussa Burm.F.) Secara Spektrofometri. Thesis. Yogyakarta: Universitas Sanata Dharma Program Study Pendidikan Biologi Universitas Sanata Dharma.

Hariyadi, B., 2011. Medicinal Plants and Traditional Medicine of Serampas Jambi. Biospecies, 4(2), pp.29-34.

Indrawan, M., 2007. Biologi Konsenvasi. Jakarta: Yayasan Obor.

Jaijesh, P. et al. 2009. Anti-Arthritic potential of the plant Justicia gendarussa Burm F, Clinics, 64(4), pp. 357-360.

Kumar Bisht V, Purohit, Vineet, 2014. Medicinal and Aromatic Plants Diversity of Asteraceae in Uttarakhand. Nature and Science, pp.121-28.

Nasrin, F., Hakim, L., Pinon, R.M., Chakraborty, M., 2015. Analgesic Study of Methanolic Extracts of Loranthus Europaeus Leaf and Stem.
World Journal of Pharmacy and Pharmaceutical Sciences, 4(07):11-9.

Makalalag, I., Wirnangsi, D.U., Baderan, D.W., 2014. Inventarisasi Jenis Tumbuhan Obat Tradisional di Kecamatan Pinolosian Kabupaten Bolaang Mongondow Selatan. Thesis. Gorontalo: Universitas Negeri Gorontalo Fakultas Matematika dan Ipa.

Ningsih, I.Y., Purwanti, D.I., Wongso, S., Prajogo, B.E.W., Indrayanto, G., 2015. Metabolite profiling of Justicia gendarussa Burm. F. leaves using UPLC-UHR-QTOF-MS. Sci Pharm, 83(3):489-500.

Pang, Y., Zhang, Y., Huang, L., Xu, L., Wang, K., Wang, D. et al., 2017 Effects and mechanisms of total flavonoids from Blumea balsamifera (L.) DC. on skin wound in rats. Int $J$ Mol Sci, 18(12):112.

Rahardjo, S.S., 2016. Review Tanaman Sembung [Blumea balsamifera (L.)], Proceeding of Mulawarman Pharmaceuticals Conferences, 3(April), pp. 18-28.

Raja Nasution, B., Aththorick, T.A., Rahayu, S., 2018. Medicinal plants used in the treatment of diabetes in karo ethnic, north sumatra, indonesia. IOP Conf Ser Earth Environ Sci, 130(1).

Rathee, P., Chaudhary, H., Rathee, S., Rathee, D., Kumar, V., Kohli, K., 2009. Mechanism of action of flavonoids as anti-inflammatory agents: A review. Inflamm Allergy - Drug Targets, 8(3):229-35.

Reid, M.C., Eccleston, C., Pillemer, K., 2015. Management of chronic pain in older adults. $B M J, 350: 1-10$

Sivasankari, B., Anandharaj, M., Gunasekaran, P., 2014. An ethnobotanical study of indigenous knowledge on medicinal plants used by the village peoples of Thoppampatti, Dindigul district, Tamilnadu, India. J Ethnopharmacol, 153(2):408-23.

Sreekeesoon, D.P., Mahomoodally, M.F., 2014. Ethnopharmacological analysis 
of medicinal plants and animals used in the treatment and management of pain in Mauritius. $J$ Ethnopharmacol, 157:181-200.

Tag, H., Kalita, P., Dwivedi, P., Das, A.K., Namsa, N.D., 2012. Herbal medicines used in the treatment of diabetes mellitus in Arunachal Himalaya, northeast, India. J Ethnopharmacol, 141(3):786-95.

Takoy, D.M., Linda, R., Lovadi, I., 2013. Tumbuhan Berkhasiat Obat Suku Dayak Seberuang di Kawasan Hutan Desa Ensabang Kecamatan Sepauk Kabupaten Sintang. J Protobiont, 2(3);122-8.
Traore, M.S., Baldé, M.A., Diallo, M.S.T., Baldé, E.S., Diané, S., Camara, A. et al., 2013. Ethnobotanical survey on medicinal plants used by Guinean traditional healers in the treatment of malaria. $J$ Ethnopharmacol, 150(3):1145-53.

Wegiera, M., Smolarz, H.D., Jedruch, M., Korczak, M., Koproń, K., 2012. Cytotoxic effect of some medicinal plants from Asteraceae family on $\mathrm{J}$ 45.01 leukemic cell line - Pilot study. Acta Pol Pharm - Drug Res, 69(2):2.

Yitno, A., 1991. Gambaran Kehidupan Masyarakat Kalimantan, Universitas Gadjah Mada, Yogyakarta. 